\title{
The clinical significance of Mda-7/IL-24 and C-myb expression in tumor tissues of patients with diffuse large $B$ cell lymphoma
}

\author{
MING MA ${ }^{1 *}$, RIYANG ZHAO ${ }^{2 *}$, XINGXIAO YANG ${ }^{3}$, LIANMEI ZHAO ${ }^{2}$, \\ LIHUA LIU $^{4}$, CONG ZHANG $^{2}$, XUEXIAO WANG ${ }^{4}$ and BAOEN SHAN ${ }^{2}$ \\ ${ }^{1}$ Clinical Laboratory; ${ }^{2}$ Research Center; Departments of ${ }^{3}$ Infection Management and ${ }^{4}$ Biotherapy, \\ The Fourth Hospital of Hebei Medical University, Shijiazhuang, Hebei 050011, P.R. China
}

Received November 11, 2017; Accepted May 14, 2018

DOI: $10.3892 /$ etm.2018.6230

\begin{abstract}
Diffuse large B cell lymphoma (DLBCL) is the most common type of non-Hodgkin's lymphoma in adults. Mda-7/IL-24 had been identified as a differentiation inducer of B phenotype lymphoma cells. Previous studies have revealed that knockdown of $\mathrm{C}$-myb also leads to the terminal differentiation of B cell lymphoma. The aim of the present study was to investigate the association between the expression of Mda-7/IL-24 and C-myb, and their prognostic significance for DLBCL patients. The tumor tissues were collected from 72 cases of DLBCL patients and detected with reverse transcription-quantitative polymerase chain reaction, western blotting and immunohistochemistry assays. The results showed that, the expression of Mda-7/IL-24 mRNA and protein was lower while the expression of C-myb was higher in DLBCL tissues, compared with the specimens of normal lymph node tissues. Furthermore, C-myb expression was negatively correlated with Mda-7/IL-24 expression at mRNA and protein levels in DLBCL tissues. The expression of Mda-7/IL-24 and C-myb in DLBCL tissues was associated with some clinicopathological parameters such as clinical stage, infiltration in bone marrow, Ki67 expression level in the tumor tissues and overall survival rates. These results indicated that low expression of Mda-7/IL-24, along with high expression of C-myb, are predictor for poor prognosis of DLBCL patients, suggesting that Mda-7/IL-24 and C-myb may be potential targets for clinical treatment of DLBCL.
\end{abstract}

Correspondence to: Professor Baoen Shan, Research Center, The Fourth Hospital of Hebei Medical University, 12 Jiankang Road, Shijiazhuang, Hebei 050011, P.R. China

E-mail: shanbaoen@sohu.com

${ }^{*}$ Contributed equally

Abbreviations: Mda-7/IL-24, melanoma differentiation associated gene7/interleukin 24; ECOG, Eastern Cooperative Oncology Group; IPI, International Lymphoma Prognosis Index; EB, ethidium bromide

Key words: Mda-7/IL-24, C-myb, diffuse large B cell lymphoma, prognosis

\section{Introduction}

Diffuse large B cell lymphoma (DLBCL) is the most common histological subtype of hematopoietic malignancy originating from lymphoid system, accounting for $\sim 40 \%$ of non-Hodgkin's lymphoma worldwide (1). Although the chemotherapy of DLBCL has been obviously improved in the past 20 years, the overall survival of a large number of DLBCL patients remains unsatisfactory, especially when they are diagnosed with bone marrow metastasis (2). Recurrence, multidrugs-resistance and metastasizing to bone marrow have become the biggest barriers for improving survival in clinical situations (3). Great efforts have been made to classify the biomarkers that could indicate prognosis and give clues about therapy, however most of them are not yet routinely applied in clinical practice. Moreover, the exact mechanisms involved in progression of DLBCL remain unclear at present. Hemopoietic tumors including DLBCL are characterized by a block in differentiation. Thus, identification of the molecules involved in the regulation of hematopoietic tumors differentiation may provide effective targets for clinical treatment of DLBCL.

Interleukin-24 (IL-24), encoded by melanoma differentiation associated gene 7 (Mda-7), was expressed at highlevels in normallymphocyts (4,5).Mda-7/IL-24 expression was found to be lost in a broad spectrum of hematopoietic malignancies, including B cells lymphoma (6,7). A novel characteristic of Mda-7/IL-24 is to inhibit growth and induce apoptosis or differentiation in various tumor cells without harming normal cells $(8,9)$. In our previous studies, we found that overexpression of Mda-7/IL-24 can exert terminal differentiation inducing effect through improving the expression of Blimp1 and inhibiting the expression of Bcl6 via activation of P38 MAPK signalling pathway in Burkitt lymphoma cells (7). This ability of Mda-7/IL-24 to induce teminal differentiation has added an entirely new dimension to understand the mechanisms involved in the progression of B cell lymphoma.

C-myb is a novel transcription factor playing important roles in regulating the differentiation of the $\mathrm{B}$ lymphocytes $(10,11)$. The overexpression of C-myb is widely observed in various hematopoietic tumors, and accumulating data has indicated that the increased expression of C-myb blocks terminal 
differentiation of B lymphoma cells $(10,11)$. Having shown that knockdown of C-myb will induce the terminal differention of Raji and Daudi cells (the B phenotype lymphoma cell lines) and recapitulate the partial characteristics similar to that caused by overexpression of Mda-7/IL-24, suggesting that there may exsit a inverse correlation between Mda-7/IL-24 and C-myb, as well as the expression of Mda-7/IL-24 and C-myb in the tumor tissues may be associated with the clinicopathological characteristics of B cell lymphoma patients.

To verificate this hypothesis, we examined the Mda-7/IL-24 and C-myb expression statuses in DLBCL, which accounts for $\sim 40 \%$ of B cells lymphoma. At the same time, we analyzed their correlations with clinicopathological parameters and evaluated the prognostic values of Mda-7/IL-24 and C-myb expressed in the tumor tissues, with the goal of laying a foundation for further study on Mda-7/IL-24 and C-myb in DLBCL. This study, for the first time, reports that Mda-7/IL-24 was attenuated and C-myb was increased in DLBCL tissues, as well as low expression of Mda-7/IL-24 and high expression of C-myb could be predictor for worse clinical condition and prognosis of DLBCL patients. These results aslo revealed that Mda-7/IL-24 and C-myb might be the potential targets in clinical therapy to be applied in DLBCL patients.

\section{Patients and methods}

Patients. The specimens of DLBCL tissues and normal lymph node tissues were collected from 72 DLBCL patients and 36 patients without carcinomas, who underwent lymph node biopsy at the Fourth Hospital of Hebei Medical University (Shijiazhuang, China). This research was approved by the Ethics Committee of the Fourth Hospital of Hebei Medical University and all informed consents were signed by patients. The median age of DLBCL cell lymphoma patient at the time of surgery was 52 years (range: $32-82$ years), and the median age of patient in control group was 47 years (range: $29-80$ years). The clinical stage, ECOG scores, IPI index and histological type were determined according to the Ann Arbor classification and the WHO classification of $2008(12,13)$. Patient's clinical information was collected and stored in a database. The specimens were collected and treated promptly after surgery. None of the DLBCL tissues patients received preoperative radiotherapy and chemotherapy. Eachspecimen was fixed in $10 \%$ formalin for making paraffin embedded blocks.

Regents. Antibodies against Mda-7/IL-24, C-myb and $\beta$-actin were purchased from Abcam (Cambridge, MA, USA). Lipofectamine ${ }^{\mathrm{TM}} 2000$ and pPACKH1TM Lentivector Packaging kit was supplied by System Biosciences (Palo Alto, CA, USA). The TRIzol reagent was purchased from Invitrogen (Shanghai, China). Go Taq ${ }^{\circledR}$ qPCR Master and Mix RevertAid $^{\mathrm{TM}}$ First Strand cDNA Synthesis kits were supplied by Promega (Madison, WI, USA).

Reverse transcription quantitative polymerase chain reaction $(R T-q P C R)$ analysis. Total RNA was extracted from the frozen stored DLBCL and normal lymph node tissues by using TRIzol reagent. The quality of RNA was assessed by EB staining analysis after agarose gel electrophoresis. RT-qPCR assay was used to analyze the expression levels of Mda-7/IL-24 and C-myb
mRNA in DLBCL and normal lymph node tissues, according to our previous protocol (2). The qPCR cycling conditions were as follows: $95^{\circ} \mathrm{C}$ for $10 \mathrm{~min}$, followed by 40 cycles of $95^{\circ} \mathrm{C}$ for $15 \mathrm{sec}, 60^{\circ} \mathrm{C}$ for $15 \mathrm{sec}$ and $60^{\circ} \mathrm{C}$ for $1 \mathrm{~min}$. The specific primers sequences (Generay Biotech Co., Ltd., Shanghai, China) for the target genes were listed in Table I. The relative level of expression of each Mda-7/IL-24 and C-myb mRNA was assessed by the $2^{-\Delta \Delta \mathrm{Ct}}$ method (2).

Western blotting analysis. To further analyze the Mda-7/IL-24 and C-myb protein expression in DLBCL tissues and their correlation. DLBCL tissues were lysed with $500 \mu 1$ of lysis buffer. The lysates were then subjected to western blotting analysis to determine the amount of Mda-7/IL-24 and C-myb. Briefly, the total proteins were subjected to agarose gel electrophoresis and were electrotransferred onto a polyvinylidene difluoride membrane. The membranes were incubated with the primary antibodies at different dilution, including antibodies to Mda-7/IL-24 (1:1,000), C-myb (1:5,000) and $\beta$-actin $(1: 5,000)$ $\mathrm{Ab}$ for $8 \mathrm{~h}$ at $4^{\circ} \mathrm{C}$. The level of Mda-7/IL-24 and C-myb in each sample was calculated as the ratio of the intensity of protein to that of $\beta$-actin, using Odyssey v3.0 software (Li-cor Biosciences, Lincoln, NE, USA).

Immunohistochemistry. Immunohistochemical assay was performed to analyze the Mda-7/IL-24 and C-myb expression in Burkitt lymphoma tissues and their relevance to the clinicopathological characteristics of patients. Briefly, the lymphoma tissues sections were dewaxed with xylene and ethanol. After antigen retrieval in a pressure kettle in Tris-EDTA buffer ( $\mathrm{pH}$ 9.0), the sections were incubated with the anti-Mda-7/IL-24 and anti-C-myb monoclonal antibodies for $3 \mathrm{~h}$ in $37^{\circ} \mathrm{C}$, and then with a horseradish peroxidase-conjugated anti-mouse secondary antibody. Protein expression level was classified based on the percentage of positive cells and the intensity of staining. Immunoreactivity was scored as following: Staining intensity $-/+,<25 \%$ positive cells; staining intensity ,$++ \geq 25$ and $<50 \%$ positive cells; staining intensity,$+++ 50-75 \%$ positive cells; and staining intensity,$++++>75 \%$ positive cells. High expression samples were cases with $\geq 50 \%$ (+++ or ++++$)$ of cells staining for Mda-7/IL-24 or C-myb (14).

Statistical analysis. All statistical analyses were performed using SPSS 13.0 software (SPSS Inc., Chicago, IL, USA). Chi-square test was used to test for significance in clinical relevance of expression of Mda-7/IL-24 and C-myb. Differences between the two independent samples were assessed by Student's t-tests. Pearson correlation was used to analyze the association of correlation between the mRNA and protein expression levels of C-myb and MDA-7/IL-24. Kaplan-Meier survival analysis and a log-rank test were used to analyze the survival curves of the DLBCL patients. $\mathrm{P}<0.05$ was considered to indicate a statistically significant difference. All data are expressed as the mean \pm standard deviation. Results shown in the figures were representative of at least three independent experiments.

\section{Results}

Associations of Mda-7/IL-24 and C-myb mRNA and protein expression in DLBCL tissues. The expression of C-myb 
Table I. Primer sequences for the reverse transcription-quantitative polymerase chain reaction.

\begin{tabular}{llll}
\hline Genes & Primer sequence & & Annealing temperature $\left({ }^{\circ} \mathrm{C}\right)$ \\
\hline Mda-7/IL-24 & Forward & 5'-CGACAGCCTCTCAAATGCAG-3' & 60 \\
& Reverse & 5'-GCTCTCCGGAATAGCAGAAACC-3' & 60 \\
$\beta$-actin & Forward & 5'-GTTGTGATGGGTTCTGA-3' & 60 \\
& Reverse & 5'-GAGCAATAGCGTCTGTG-3' & 60 \\
& Forward & 5'-CTGCCTGGACGAACTGATAATG-3' & \\
\hline
\end{tabular}

Mda-7/IL-24, melanoma differentiation associated gene7/interleukin 24.

Table II. Results of IHC staining of 72 cases of human DLBCL tissue samples.

\begin{tabular}{lrr}
\hline & \multicolumn{2}{c}{ Mda-7/IL-24 } \\
\cline { 2 - 3 } C-myb & +-++ & +++-++++ \\
\hline+-++ & 5 & 30 \\
+++-++++ & 35 & 2 \\
\hline
\end{tabular}

Mda-7/IL-24, melanoma differentiation associated gene7/interleukin 24; IHC, immunohistochemistry; DLBCL, diffuse large B cell lymphoma.

mRNA and protein in DLBCL and normal lymph node tissues was analyzed using Student's t-test (Figs. 1 and 2). As shown in Figs. 1A and 2A, the DLBCL tissues showed significantly decreased expression of Mda-7/IL-24 and increased expression of C-myb mRNA and protein, compared with normal lymph node tissues. At mRNA level, the relative optical densities of Mda-7/IL-24 and C-myb were $0.38 \pm 0.12$ and $0.52 \pm 0.09$ respectively, and the expression of $\mathrm{C}-\mathrm{myb}$ was negatively correlated with Mda-7/IL-24 in DLBCL tissues (Fig. 1B, $\mathrm{r}=-0.4322, \mathrm{P}<0.01$ ). At protein level, the relative optical densities of Mda-7/IL-24 and C-myb were 0.46 \pm 0.06 and $0.57 \pm 0.05$ respectively, and the expression of $\mathrm{C}$-myb was aslo negatively correlated with Mda-7/IL-24 in DLBCL tissues (Fig. 1B, r=-0.4649, $\mathrm{P}<0.01$ ), indicating that there may exsit a negative regulation relationship between Mda-7/IL-24 and C-myb expression.

Associations of Mda-7/IL-24 and C-myb expression with clinicopathological parameters of DLBCL patients. In DLBCL tissues, the staining of Mda-7/IL-24 was found on the cytoplasm of most tumor cells and nucleus of a few cells (Fig. 3), while C-myb occurred on the cell nucleus. High expression of the Mda-7/IL-24 and C-myb protein was found in 32 (44.44\%) and $37(51.39 \%)$ cases of tumor tissues respectively, while high expression of Mda-7/IL-24 and low expression of C-myb were detected in all of the normal lymph node tissues. These findings were in good agreement with the results of RT-qPCR and western blotting assays that tumor tissues from patients with DLBCL showed significantly lower Mda-7/IL-24 and higher C-myb mRNA and protein expression, compared with the normal lymph node tissues. Moreover, the results of IHC staining aslo showed that expression of C-myb was negatively correlated with Mda-7/IL-24 in DLBCL tissues (Table II, $\left.\chi^{2}=46.981, \mathrm{P}<0.01\right)$.

To characterize the clinical significance of Mda-7/IL-24 and C-myb in DLBCL, we analyzed the relationship between the Mda-7/IL-24 or C-myb expression in tumor tissues and clinicopathological parameters of patients with DLBCL. As shown in Tables III and IV, the expression of Mda-7/IL-24 and C-myb protein was significantly related with the clinical stage, bone marrow metastasis status, Ki67 expression and IPI index, while not related with sex, age and ECOG scores. DLBCL patients with early clinical stage (stage I and II), low Ki67 positive rate $(\leq 80)$, low IPI index $(\leq 2)$, and negative bone marrow infiltration, had significantly higher expression of Mda-7/IL-24 and lower expression of C-myb than those with advanced clinical stage (stage III and IV), high Ki67 positive rate $(>80)$, positive bone marrow infiltration and high IPI index ( $>2)$, indicating a correlation between Mda-7/IL-24 or $\mathrm{C}$-myb expression and bioactivities, progression and prognosis of DLBCL. Taken together, the low expression of Mda-7/IL-24 and high expression of C-myb could be predictor for worse clinical condition and prognosis of patients with DLBCL.

Correlation of Mda-7/IL-24 and C-myb expression with tumor-specific survival for DLBCL patients. All of the 72 cases of DLBCL patients were treated with routine chemotherapy agents and rituximab. Kaplan-Meier survival curves showed that lower Mda-7/IL-24 or higher C-myb expression was associated with the worse overall and progression-free survival (log-rank test: $\mathrm{P}<0.01$; Fig. 4). The five-year overall survival rate for patients with high Mda-7/IL-24 expression in tumor tissues was 90.63 and $75.00 \%$ for those with low expression, indicating that DLBCL patients with low Mda-7/IL-24 expression in tumor tissue had a worse prognosis than those with high expression $(\mathrm{P}<0.01)$. In addition, the five-year overall survival rate for patients with high C-myb expression in tumor tissues was 74.29 and $91.89 \%$ for those with low expression, suggesting that DLBCL patients with high $\mathrm{C}$-myb expression in tumor tissue aslo had a poorer prognosis than those with low expression $(\mathrm{P}<0.01)$. Moreover, the better overall and progression-free survival of DLBCL patients with high Mda-7/IL-24 suggested that Mda-7/IL-24 may play a novel role in affecting the chemosensitivity of the tumor cells, which was in good agreement with our previous finding 
A

$\begin{array}{llllll}\text { N1 } & \text { P1 } & \text { N2 } & \text { P2 } & \text { N3 } & \text { P3 }\end{array}$

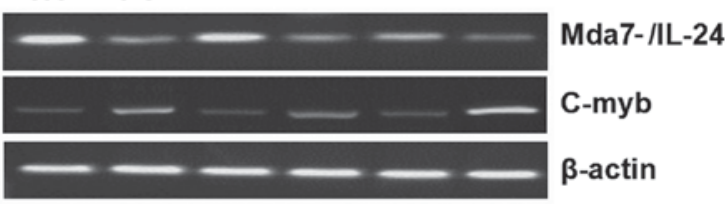

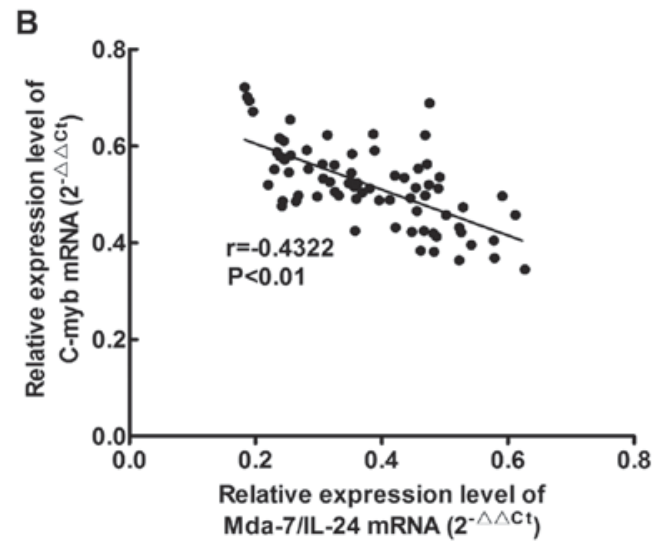

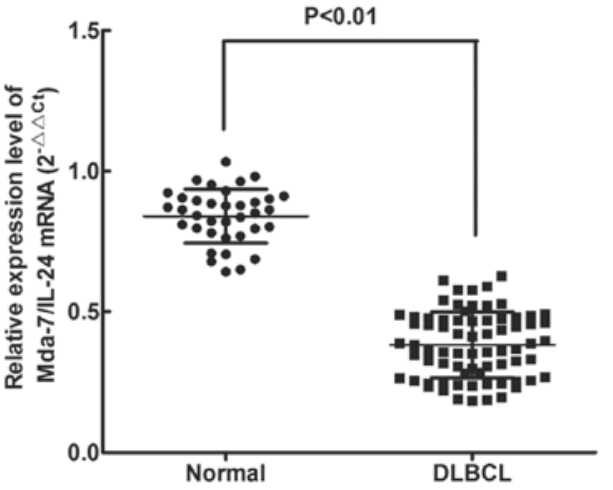

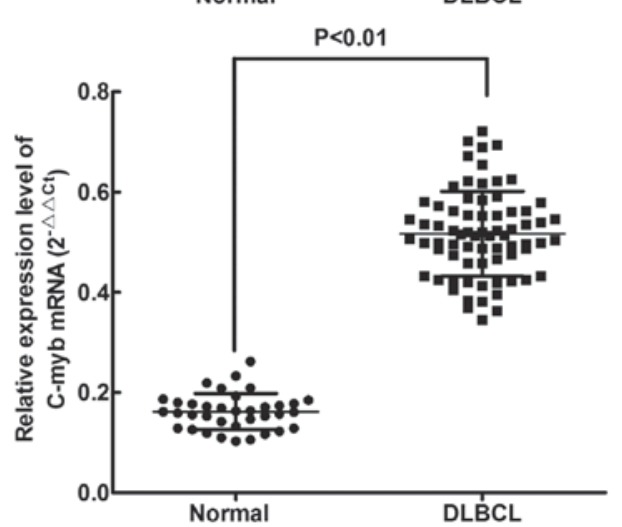

Figure 1. Associations of mRNA expression between Mda-7/IL-24 and C-myb in DLBCL tissues. (A) Mda-7/IL-24 and C-myb mRNA expression was analyzed by RT-qPCR assay; $\beta$-actin as a loading control. N1, N2 and N3: Normal lymph node tissues from three contibutors; P1, P2 and P3: The DLBCL tissues from three patients. Normal: Normal lymph node tissues; DLBCL: Tumor tissues from patients with DLBCL. (B) The relationship between expression of Mda-7/IL-24 and C-myb mRNA in the tumor tissues from 72 cases of DLBCL patients was analyzed. Mda-7/IL-24, melanoma differentiation associated gene7/interleukin 24; IHC, immunohistochemistry; DLBCL, diffuse large B cell lymphoma.

A

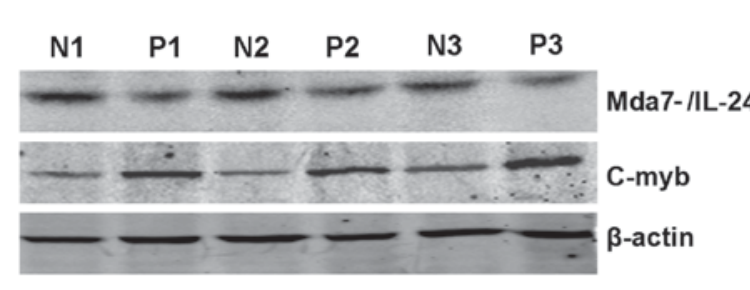

B

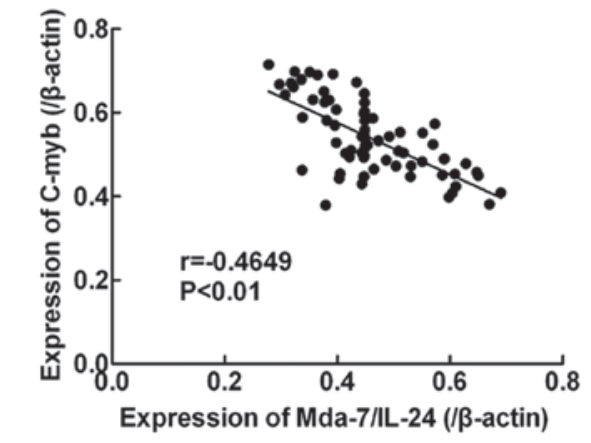

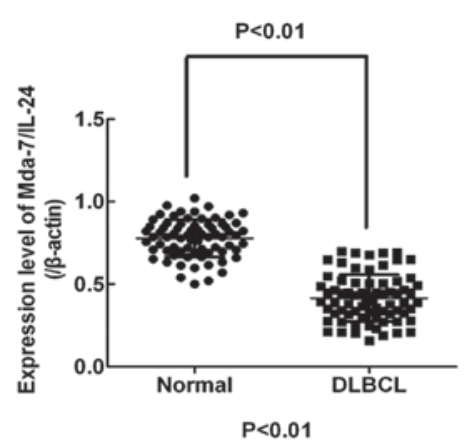

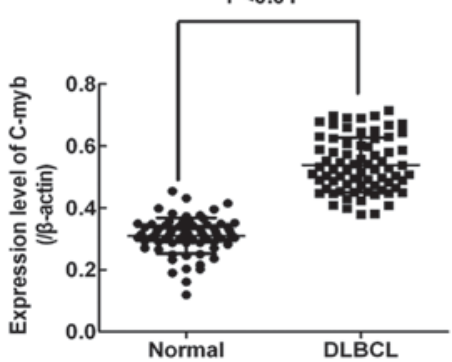

Figure 2. Associations of protein expression between Mda-7/IL-24 and C-myb in DLBCL tissues. (A) Mda-7/IL-24 and C-myb protein expression was analyzed by western blotting assay; $\beta$-actin as a loading control. N1, N2 and N3: Normal lymph node tissues from three contibutors; P1, P2 and P3: The DLBCL tissues from three patients. Normal: Normal lymph node tissues; DLBCL: Tumor tissues from patients with DLBCL. (B) The relationship between expression of Mda-7/IL-24 and C-myb protein in the tumor tissues from 72 cases of DLBCL patients was analyzed. Mda-7/IL-24, melanoma differentiation associated gene7/ interleukin 24; IHC, immunohistochemistry; DLBCL, diffuse large B cell lymphoma.

that transfection with exogenous Mda-7/IL-24 improved the sensitivity of B phenotype lymphoma cells to chemotherapy agents in vitro (2).
In summary, these analyses demonstrated that low Mda-7/IL-24 expression and high C-myb expression in DLBCL tissues were associated with poor prognosis. These results 
Table III. Association between Mda-7/IL-24 expression and clinicopathological parameters of patients with DLBCL.

\begin{tabular}{|c|c|c|c|c|}
\hline \multirow[b]{2}{*}{ Parameters } & \multicolumn{2}{|c|}{ Mda-7/IL-24 expression } & \multirow[b]{2}{*}{$\chi^{2}$} & \multirow[b]{2}{*}{ P-value } \\
\hline & High & Low & & \\
\hline \multicolumn{5}{|l|}{ Sex } \\
\hline Male & 20 & 23 & \multirow[t]{2}{*}{0.185} & \multirow[t]{2}{*}{0.667} \\
\hline Female & 12 & 17 & & \\
\hline \multicolumn{5}{|l|}{ Age (years) } \\
\hline$>60$ & 15 & 16 & \multirow[t]{2}{*}{0.343} & \multirow[t]{2}{*}{0.558} \\
\hline$\leq 60$ & 17 & 24 & & \\
\hline \multicolumn{5}{|l|}{ Clinical stages } \\
\hline I-II & 20 & 15 & \multirow[t]{2}{*}{4.448} & \multirow[t]{2}{*}{0.035} \\
\hline III-IV & 12 & 25 & & \\
\hline \multicolumn{5}{|c|}{ Infiltration in bone marrow } \\
\hline No infiltration & 18 & 11 & \multirow[t]{3}{*}{25.779} & \multirow[t]{3}{*}{$<0.001$} \\
\hline Infiltration $(<25 \%)$ & 10 & 12 & & \\
\hline Infiltration $(\geq 25 \%)$ & 4 & 17 & & \\
\hline \multicolumn{5}{|l|}{ Ki 67 positive rate (\%) } \\
\hline$>80$ & 9 & 26 & \multirow[t]{2}{*}{9.667} & \multirow[t]{2}{*}{0.002} \\
\hline$\leq 80$ & 23 & 14 & & \\
\hline \multicolumn{5}{|l|}{ ECOG scores } \\
\hline$>2$ & 14 & 19 & \multirow[t]{2}{*}{0.101} & \multirow[t]{2}{*}{0.751} \\
\hline$\leq 2$ & 18 & 21 & & \\
\hline \multicolumn{5}{|l|}{ IPI index } \\
\hline$>2$ & 11 & 24 & \multirow[t]{2}{*}{4.673} & \multirow[t]{2}{*}{0.031} \\
\hline$\leq 2$ & 21 & 16 & & \\
\hline
\end{tabular}

Mda-7/IL-24, melanoma differentiation associated gene7/interleukin 24; ECOG, Eastern Cooperative Oncology Group; IPI, International Lymphoma Prognosis Index; DLBCL, diffuse large B cell lymphoma.

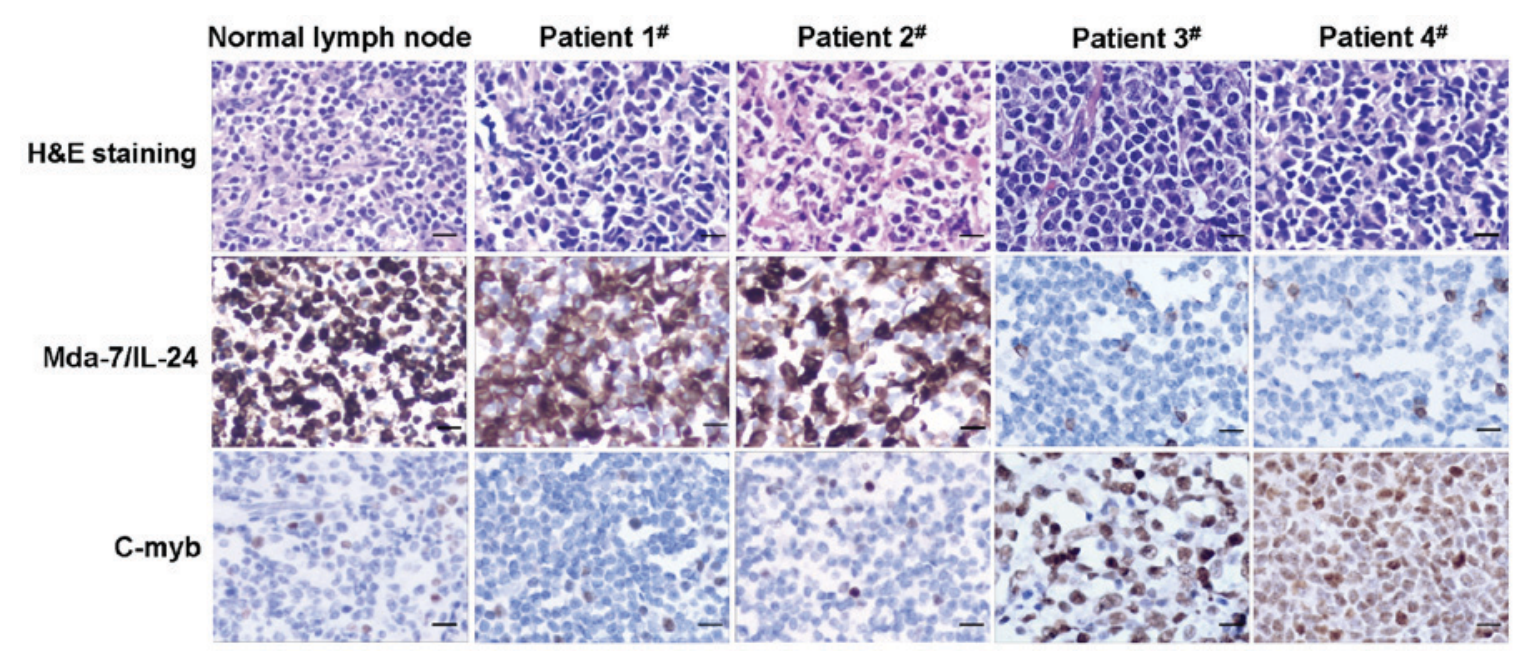

Figure 3. Immunohistochemical analysis of Mda-7/IL-24 and C-myb expression in human DLBCL tissues. Magnification, x400. In DLBCL tissues, the staining of Mda-7/IL-24 was found on the cytoplasm of most tumor cells and nucleus of a few cells, while C-myb occurred on the cell nucleus. Patient $1^{\# \text {, }}$ patient $2^{\#}$, patient $3^{\#}$ and patient $4^{\#:}$ The DLBCL tissues from four cases of patients. Scale bars, $20 \mu \mathrm{m}$. Mda-7/IL-24, melanoma differentiation associated gene7/ interleukin 24; IHC, immunohistochemistry; DLBCL, diffuse large B cell lymphoma.

could provide some evidence that simultaneous assaying the expression of Mda-7/IL-24 and C-myb in tumor tissues might be more accurate for prognosis of patients with DLBCL.

\section{Discussion}

In the present study, we analyzed the Mda-7/IL-24 and 
Table IV. Association between C-myb expression and clinicopathological parameters of patients with DLBCL.

\begin{tabular}{|c|c|c|c|c|}
\hline \multirow[b]{2}{*}{ Parameters } & \multicolumn{2}{|c|}{ C-myb expression } & \multirow[b]{2}{*}{$\chi^{2}$} & \multirow[b]{2}{*}{ P-value } \\
\hline & High & Low & & \\
\hline \multicolumn{5}{|l|}{ Sex } \\
\hline Male & 24 & 19 & 1.335 & 0.248 \\
\hline Female & 13 & 16 & & \\
\hline \multicolumn{5}{|l|}{ Age (years) } \\
\hline$>60$ & 15 & 16 & 0.196 & 0.658 \\
\hline$\leq 60$ & 22 & 19 & & \\
\hline \multicolumn{5}{|l|}{ Clinical stages } \\
\hline I-II & 10 & 25 & 14.195 & $<0.001$ \\
\hline III-IV & 27 & 10 & & \\
\hline \multicolumn{5}{|c|}{ Infiltration in bone marrow } \\
\hline No infiltration & 10 & 19 & 22.582 & $<0.001$ \\
\hline Infiltration $(<25 \%)$ & 12 & 10 & & \\
\hline Infiltration $(\geq 25 \%)$ & 15 & 6 & & \\
\hline \multicolumn{5}{|l|}{ Ki 67 positive rate (\%) } \\
\hline$>80$ & 24 & 11 & 8.049 & 0.005 \\
\hline$\leq 80$ & 13 & 24 & & \\
\hline \multicolumn{5}{|l|}{ ECOG scores } \\
\hline$>2$ & 20 & 13 & 2.072 & 0.150 \\
\hline$\leq 2$ & 17 & 22 & & \\
\hline \multicolumn{5}{|l|}{ IPI index } \\
\hline$>2$ & 25 & 10 & 10.112 & 0.001 \\
\hline$\leq 2$ & 12 & 25 & & \\
\hline
\end{tabular}

Mda-7/IL-24, melanoma differentiation associated gene7/interleukin 24; ECOG, Eastern Cooperative Oncology Group; IPI, International Lymphoma Prognosis Index; DLBCL, diffuse large B cell lymphoma.

C-myb expression in tumor tissue samples and their relevance to the clinicopathological characteristics of DLBCL patients. Although Mda-7/IL-24 has been widely regarded as an anti-tumor molecule and has been shown to inhibit the growth of various hematopoietic carcinomas (4), little is known about its clinical role in patients with DLBCL. Attenuated expression of Mda-7/IL-24 was found in acute myeloid leukemia and Burkitt lymphoma cells $(3,4,15)$. The decreased expression of Mda-7/IL-24 was thought to be associated with numerous tumor biological characteristics, such as differentiation blockage, malignant proliferation, invasion and chemotherapy resistance $(4,16-18)$. Our previous studies have shown that transfection of endogenous Mda-7/IL-24 induced terminal differentiation of Burkitt lymphoma cells, which was characterized by growth inhibition, morphological and cell surface antigens changes and decreased expression of malignant markers (7). Furthermore, C-myb is an innate regulatory transcription factor contributing to differentiation blockage in a variety of hematopoietic malignancy. Chen et al (15) had reported that knockdown of C-myb resulted in significantly decreased expression of CD10 and increased expression of CD45 and CD138 in Raji and Daudi cells, indicating the mature differentiation of the two types of B lymphoma cells. Thus, elucidating the correlations of expression of Mda-7/IL-24 and C-myb with the clinicopathological parameters is necessary for us to understand the novel function of Mda-7/IL-24 and C-myb involved in progression of B cell lymphoma.

More importantly, whether overexpressing Mda-7/IL-24 or sliencing C-myb in Raji and Daudi cells will led to the increased expression of Blimp1, the key factor in controlling transcriptional network that improves the terminal differentiation of B cells (7,19-21). The same target molecular in the downstream of Mda-7/IL-24 and C-myb led to our hypothesis that there may exsit a negtive regulation between Mda-7/IL-24 and C-myb, as well as the expression of Mda-7/IL-24 and $\mathrm{C}$-myb in the tumor tissues may be associated with the clinicopathological characteristics and prognosis of patients with B cell lymphoma.

To verificate this hypothesis, we analyzed the expression of Mda-7/IL-24 and C-myb in tumor tissues from patients with DLBCL using RT-qPCR and western blotting assays. The results showed that the expression of Mda-7/IL-24 was significantly decreased, while the expression of C-myb was increased in DLBCL tissues both in mRNA and protein levels, compared with normal lymph node tissues. Furthermore, we found that aberrant low expression of Mda-7/IL-24 and high expression of C-myb were positively correlated with Ki67 
A

- Mda-7/IL-24 high expression

-L. Mda-7/LL-24 low expression

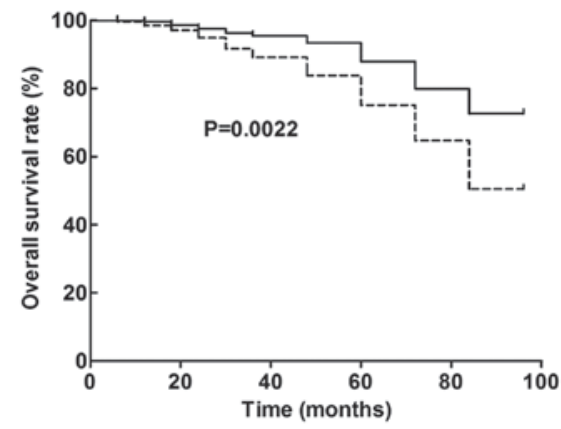

B

- Mda-7/IL-24 high expression -L. Mda-7/LL-24 low expression

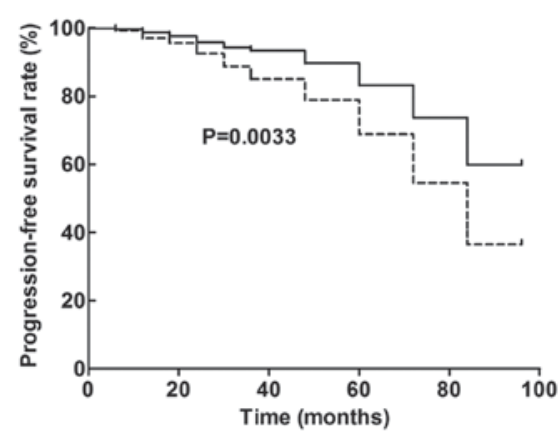

+ C-myb high expression

-ᄂ. C-myb low expression

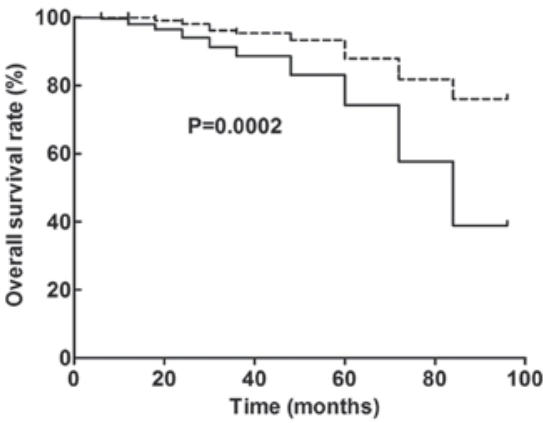

- C-myb high expression

-L. C-myb low expression

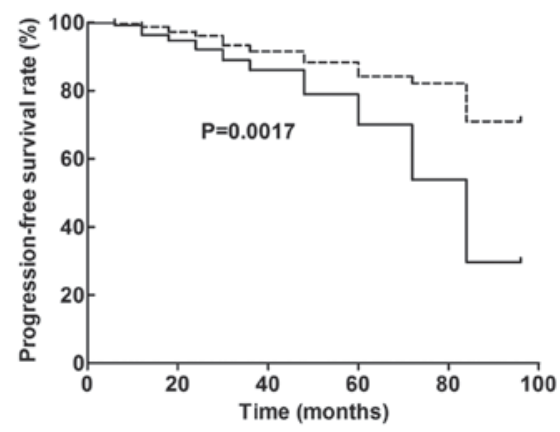

Figure 4. Kaplan-Meier univariate survival analysis of Mda-7/IL-24 and C-myb expression in tumor tissue with a log-rank test for DLBCL patients (n=72). (A) Analysis of Mda-7/IL-24 and C-myb expression in tumor tissues, showing the correlation between Mda-7/IL-24 (left) and C-myb (right) expression and overall survival of patients with DLBCL. (B) Analysis of Mda-7/IL-24 and C-myb expression in tumor tissues, showing the correlation between Mda-7/IL-24 (left) and C-myb (right) expression and progression-free survival of patients with DLBCL. Mda-7/IL-24, melanoma differentiation associated gene7/ interleukin 24; DLBCL, diffuse large B cell lymphoma.

positive rate, malignant grade, bone morrow metastases and IPI index. In addition, the Kaplan-Meier survival curves aslo revealed that the expression of Mda-7/IL-24 and C-myb was significantly associated with overall and progression-free survival of DLBCL patients. Patients with lower Mda-7/IL-24 and higher $\mathrm{C}$-myb expression were associated with worse overall and progression-free survival, suggesting that low expression of Mda-7/IL-24 and high expression of C-myb in tumor tissue could be predictor for poor prognosis of DLBCL. Additionally, the better prognosis of DLBCL patients with high Mda-7/IL-24 expression aslo suggested that Mda-7/IL-24 may play a novel role in affecting the chemosensitivity of the tumor cells, which was in good agreement with our previous finding that overpression of Mda-7/IL-24 can improve the sensitivity of B phenotype lymphoma cells to chemotherapy agents in vitro (2).

In conclusion, although there have been investigation on Mda-7/IL-24 expression status in a varity of tumors (22-24), this is the first study to analyze its association with $\mathrm{C}$-myb in DLBCL patients to value their prognostic significances. Low expression of Mda-7/IL-24, along with high expression of C-myb, are associated with worse clinical condition and outcomes of DLBCL patients. The present study also revealed that Mda-7/IL-24 and C-myb could be novel biomarkers and prognostic targets to establish new therapeutic strategies for improving the prognosis of DLBCL patients.

\section{Acknowledgements}

Not applicable.

\section{Funding}

The present study was partially supported by the Natural Science Foundation of China (grant no. 81372200), the Natural Science Foundation of China of Hebei Province (grant no. H2015206376) and Health department of Hebei province (grant no. 20160171).

\section{Availability of data and materials}

The datasets used and/or analyzed during the current study are available from the corresponding author on reasonable request.

\section{Authors' contributions}

MM and RZ designed the present study, summarized and analyzed data, and interpreted the manuscript. XY and LZ collected and analyzed the data. XW, CZ and LL collected data and wrote the manuscript; BS designed the present study, interpreted the data, and had final approval of the manuscript. All authors reviewed the manuscript and consented for publication. 


\section{Ethics approval and consent to participate}

This research was approved by the Ethics Committee of the Fourth Hospital of Hebei Medical University and all informed consents were signed by patients.

\section{Consent for publication}

Not applicable.

\section{Competing interests}

The authors declare that they have no competing interests.

\section{References}

1. Li J, Fu R, Yang L and Tu W: miR-21 expression predicts prognosis in diffuse large B-cell lymphoma. Int J Clin Exp Pathol 8: $15019-15024,2015$

2. Ma M, Zhao L, Sun G, Zhang C, Liu L, Du Y, Yang X and Shan BE: Mda-7/IL-24 enhances sensitivity of B cell lymphoma to chemotherapy drugs. Oncol Rep 35: 3122-3130, 2016.

3. Yang BX, Duan YJ, Dong CY, Zhang F, Gao WF, Cui XY, Lin YM and Ma XT: Novel functions for mda-7/IL-24 and IL-24 delE5: Regulation of differentiation of acute myeloid leukemic cells. Mol Cancer Ther 10: 615-625, 2011.

4. Dong CY, Zhang F, Duan YJ, Yang BX, Lin YM and Ma XT: mda-7/IL-24 inhibits the proliferation of hematopoietic malignancies in vitro and in vivo. Exp Hematol 36: 938-946, 2008.

5. Hosseini E, Hosseini SY, Hashempour T, Fattahi MR and Sadeghizadeh M: Effect of RGD coupled MDA-7/IL-24 on apoptosis induction in a hepatocellular carcinoma cell line. Mol Med Rep 15: 495-501, 2017.

6. Huo W, Li ZM, Zhu XM, Bao YM and An LJ: MDA-7/IL-24 suppresses tumor adhesion and invasive potential in hepatocellular carcinoma cell lines. Oncol Rep 30: 986-992, 2013.

7. Ma M, Yang X, Zhao L, Liu L, Zhang C, Wang X and Shan B Mda-7/IL-24 induces the differentiation of B cell lymphoma via activation of the P38 mitogen activated protein kinase signaling pathway. Mol Med Rep 16: 5633-5642, 2017

8. Liu X, Zhou H, Huang X, Cui J, Long T, Xu Y, Liu H, Yu R, Zhao R, Luo $\mathrm{G}$, et al: A broad blockade of signaling from the IL-20 family of cytokines potently attenuates collagen-induced arthritis. J Immunol 197: 3029-3037, 2016.

9. Panneerselvam J, Srivastava A, Muralidharan R, Wang Q, Zheng W, Zhao L, Chen A, Zhao YD, Munshi A and Ramesh R: IL-24 modulates the high mobility group (HMG) $\mathrm{A} 1 / \mathrm{miR} 222 / \mathrm{AKT}$ signaling in lung cancer cells. Oncotarget 7: 70247-70263, 2016

10. Piovesan D, Tempany J, Di Pietro A, Baas I, Yiannis C, O'Donnell K, Chen Y, Peperzak V, Belz GT, Mackay CR, et al: c-Myb regulates the T-bet-dependent differentiation program in B cells to coordinate antibody responses. Cell Rep 19: 461-470, 2017.
11. Iżykowska K, Przybylski GK, Gand C, Braun FC, Grabarczyk P, Kuss AW, Olek-Hrab K, Bastidas Torres AN, Vermeer MH, Zoutman WH, et al: Genetic rearrangements result in altered gene expression and novel fusion transcripts in Sézary syndrome. Oncotarget 8: 39627-39639, 2017.

12. Jaffe ES: The 2008 WHO classication of lymphomas: Implications for clinical practice and translational research. Hematology Am Soc Hematol Educ Program: 523-531, 2009.

13. Zelenetz AD, Gordon LI, Wierda WG, Abramson JS, Advani RH, Andreadis CB, Bartlett N, Byrd JC, Czuczman MS, Fayad LE, et al: Non-Hodgkin's lymphomas, version 4.2014. J Natl Compr Canc Netw 12: 1282-1303, 2014.

14. Xu SL, Oshima T, Imada T, Musuda M, Debnath B, Grande F, Garofalo A and Neamati N: Stabilization of MDA-7/IL-24 for colon cancer therapy. Cancer Lett 335: 421-430, 2013.

15. Chen S, Wang Z, Dai X, Pan J, Ge J, Han X, Wu Z, Zhou X and Zhao T: Re-expression of microRNA-150 induces EBV-positive Burkitt lymphoma differentiation by modulating c-Myb in vitro. Cancer Sci 104: 826-834, 2013.

16. Cheng HR, Wu BQ, Chen L, Zhang ZX and Li B: Expression and effect of serum interleukin-24 level on bone marrow mononuclear cells in children with acute leukemia. Genet Mol Res 14: 17281-17288, 2015.

17. Patani N, Douglas-Jones A, Mansel R, Jiang W and Mokbel K: Tumour suppressor function of MDA-7/IL-24 in human breast cancer. Cancer Cell Int 10: 29, 2010.

18. Galimova E, Rätsep R, Traks T, Kinggo K, Escott-price V and Kõks S: Interleukin-10 family cytokines pathway: Genetic variants and psoriasis. Br J Dermatol 176: 1577-1587, 2017.

19. Sang M, Hulsurkar M, Zhang X, Song H, Zheng D, Zhang Y, $\mathrm{Xu}$ J, Zhang S, Ittmann M and Li W: GRK3 is a direct target of CREB activation and regulates neuroendocrine differentiation of prostate cancer cells. Oncotarget 7: 45171-45185, 2016.

20. Xia Y, Xu-Monette ZY, Tzankov A, Li X, Manyam GC, Murty V, Bhagat G, Zhang S, Pasqualucci L, Visco C, et al: Loss of PRDM1/BLIMP-1 function contributes to poor prognosis of activated B-cell-like diffuse large B-cell lymphoma. Leukemia 31: 625-636, 2017.

21. Chan YH, Chiang MF, Tsai YC, Su ST, Chen MH, Hou MS and Lin KI: Absence of the transcriptional repressor Blimp-1 in hematopoietic lineages reveals its role in dendritic cell homeostatic development and function. J Immunol 183: 7039-7046, 2009.

22. Pradhan AK, Talukdar S, Bhoopathi P, Shen XN, Emdad L, Das SK, Sarkar D and Fisher PB: Mda-7/IL-24 mediates cancer cell-specific death via regulation of miR-221 and the beclin-1 axis. Cancer Res 77: 949-959, 2017.

23. Ma YF, Ren Y, Wu CJ, Zhao XH, Xu H, Wu DZ, Xu J, Zhang XL and Ji Y: Interleukin (IL)-24 transforms the tumor microenvironment and induces anticancer immunity in a murine model of colon cancer. Mol Immunol 75: 11-20, 2016.

24. Lv C, Su Q, Liang Y, Hu J and Yuan S: Oncolytic vaccine virus harbouring the IL-24 gene suppresses the growth of lung cancer by inducing apoptosis. Biochem Biophys Res Commun 476: $21-28,2016$

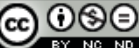

This work is licensed under a Creative Commons Attribution-NonCommercial-NoDerivatives 4.0 International (CC BY-NC-ND 4.0) License. 